\title{
The impact of Training and Employees' Productivity at General Directorate of Residency and Foreigners Affairs in the U.A.E
}

\author{
Rashid Ali Al Ali, Rosman MD Yusoff, Fadillah Binti Ismail, Adnan Ali Alhisani
}

\begin{abstract}
Today, many organizations of different sizes are facing challenges related to the performance and the productivity of labor. Training is main factor to improve the performance of employees which contributes positively to their productivity. This study discusses the training its influence on the productivity in the General Directorate of Residency and Foreigners Affairs (GDRFA) in the U.A.E. The problem is the weak job performance as a result of unsuitable training programs that leads to poor outcomes from employees at the end of the training. This outcome shows the importance of training on developing the overall employees' productivity at work. The empirical result of this study indicates that training is correlated with employees' productivity. Thus, the employees' productivity together with effective training programs.
\end{abstract}

Index Terms: GDRFA, U.A.E, Training, Employees, Productivity.

\section{INTRODUCTION}

Training is a useful practice that has specific objectives of improving individuals' capability, learning ability, performance and productivity (Trevisani, 2016). Training is the process of teaching, developing the skills and knowledge of individuals that relate to particular useful competencies. The principles of training come from the center of preparations and provide the pillar of development in modern organizations (Sultana et al., 2012). Today, most organizations need continuous development through continuous training to maintain the skills and knowledge of employees by continuous upgrading throughout their working life (Lindström, 2013).

Nowadays in the UAE training is the most critical factor to increase the efficiency of employees and of organization doing business in the UAE. However, the most critical factor of employee productivity is training because practicing continuous development through training which is very important to enhance the capabilities of employees as well as

\section{Revised Manuscript Received on September 22, 2019}

Rashid Ali Al Ali, Faculty of Technology Management, Universiti Tun Hussein Onn Malaysia, 86400 Parit Raja, Batu Pahat, Johor, Malaysia. rashed_alalili@hotmail.com

Rosman MD Yusoff, Centre for General Studies and Co-Curricular, Univeristi Tun Hussein Onn Malaysia, 86400 Parit Raja, Batu Pahat, Johor, Malaysia.rosmanmy@uthm.edu.my

Fadillah Binti Ismail, Faculty of Technology Management, Universit Tun Hussein Onn Malaysia, 86400 Parit Raja, Batu Pahat, Johor, Malaysia. fadillah@uthm.edu.my

Adnan Ali Alhisani, Faculty of Technology Management, Universiti Tun Hussein Onn Malaysia, 86400 Parit Raja, Batu Pahat, Johor, Malaysia. dnanvip@hotmail.com. the productivity of public companies in the UAE. The experienced employees perform better because with experience their skills and competencies increase (Fakhar and Anwar, 2008). Now days, organizations are facing hurdles in taking the maximum advantage from training programs. According to the Global Competitiveness Report for the year 2016-2017 for competition in productivity, the UAE has taken the highest rank among other Arab countries and Gulf region but ranked 16th globally despite the enormous efforts of the government to increase the productivities of local companies and the overall performance. Scholars have found that majority of the most of the organizations are unfamiliar with the nature of the training programs and modern theory in training because there is a lack of understanding implementing training methods correctly so that to enhance the productivity (Sultana, 2012).

This study is an attempt to discuss the effect of training on the productivity of employees in GDRFA at UAE. This study examine the impact of training on employees' productivity in the UAE public organizations.

\section{LITERATURE REVIEW}

\section{A. Training}

The quality of the human resource is important for organizational profitability. Therefore, the organization has to constantly seek to improve the quality of its workforce. An easy way of achieving this is by training. The core of strength for every organization mainly comes from its employees. Trained employees become the strong foundation for the success of the organisation in the future. Thus managers should develop themselves and commit to developing the potential of their employees. Training boosts employees' initiative and the quality of work, herewith encouraging them to be more committed to achieving the organizational objectives and goals and in turn promoting the employees' efficiency in the organization (Nda and Fard, 2013).

Robert (2006) suggested that organizations can gain competitive advantage through improving performance with continuous learning. The organizations should focus on enhancing productivity by following the best human resource usage and the investment in training and development. Therefore, employees' training is must for any organization. It helps to carry out responsibilities and perform roles effectively. Additionally it provides an opportunity to learn new things. Thus, 
employees become prepare to take up more and higher responsibilities in the future. The quality of training varies from one organization to organization; this is because of different factors i.e. the grade of external change, new processes, or new markets.

The measurement of training in this study is based on the theory developed by the scientist in management Donald Kirkpatrick wrote articles on the evaluations of training programs. These articles have been published in 1994 and were used to establish the original ideas published in 1959 as the famous theory of training evaluation. In order to demonstrate the value of training this model is applied before, during and after training. The theory of Donald Kirkpatrick (four levels of training evaluation) as shown in Figure-1 has become the most widely used theory in training evaluation.

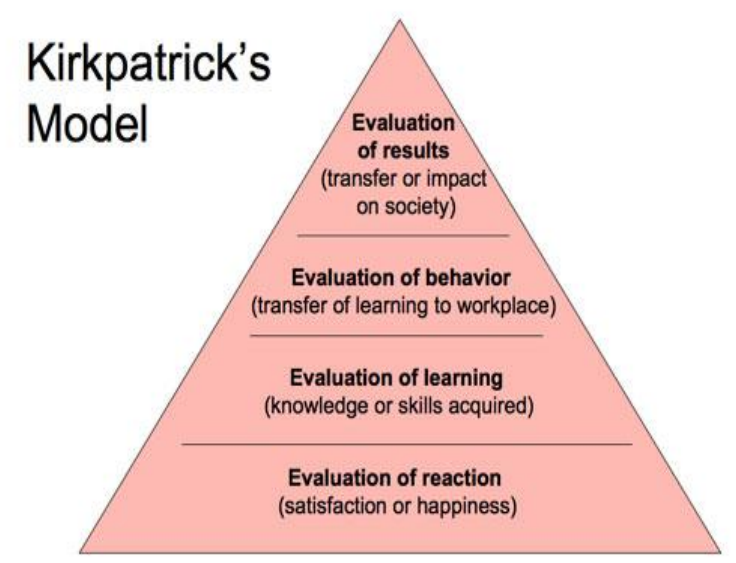

Fig 1: The levels of Kirkpatrick Model

Source: Kirkpatrick \& Kirkpatrick, 2006

Reaction evaluates the participants' response to the training. Learning determines if participants learned the material. Behavior mentions that if the participants' are using what they learned on the job; and results evaluate the impact of overall training.

\section{B. Employees' Productivity}

Employees' productivity is a dependent variable. Previous studies defined it as an indicator of inputs and outputs of employees. This indicates that the productivity of the workforce is the motive and all training. In all organizations, employee productivity broadly depends on motivating and directing the employees to achieve organizational goals and objectives. It is commonly known that discipline practices and work environment factors also affect the productivity of the workforce (Haynes, 2007; Koopmans et al., 2011)

However, this study defines 'employee productivity' as a measure of the ratio between the input and output of employee's outcome to his/her organization.

\section{The Relationship between Training and Employees' Productivity}

Prada (2019) indicate large positive effects of the training program on store-level productivity. The major aim of effective training and development programs is to improve the productivity of employees. Training could be provided by various and several methods and styles within the public organization such as peers' cooperation, coaching and mentoring and the subordinates' participation. This teamwork helps and enables the employees to participate actively on the job and increase their productivity. Abomeh (2015) revels that organization can achieve optimum returns through investing in employee training program and through effective management of trained employees. Training programs increase productivity and help the organization to make the best use of their human resources in to gain competitive advantage. Therefore, it is essential for organizations to plan for such training programs to enhance employees' abilities and competencies. Further, Konings (2015) mentions that the productivity premium of a trained worker is substantially higher compared to the wage premium.

This reveals shows that training increases job productivity due to increases efficiencies of performance, enhance the knowledge of employees, increases capacity to adopt new technologies and methods associated with the work. Thus, it can be revealed that training affects employees' productivity in a direct and causal relationship. Therefore, this study will test the following hypothesis,

$\mathrm{H} 1$ : There is a positive relationship between training and employees' productivity.

\section{METHODOLOGY}

This is causal research in which the researcher tests a set of hypotheses concerning causal correlations between certain variables. Thus, the objective of selecting the methodology in this study is to specify the independent variable and its effect on dependent variable. Therefore a causal research should be adopted to test the hypothesis and model developed in this research. This study has used a quantitative methodology to test the connections and relationships between independent and dependent variable.

The survey is conducted in the GDRFA at UAE. The population of any study is a specific number of individuals who are deemed to have related characteristics. It is evident that specific individuals within a particular population have binding attributes. Therefore, a certain population represents a group of participants taken from the whole population who share a similar characteristic, such as gender, job, age, and experience (Saunders et al., 2011). Table 1 shows the criteria for sample size which is followed Krejcie and Morgan's sampling table. For the population of 5881 the recommended sample size is 360 respondents approximately. However, the researcher increased the sample size to 387 in order to increase the reliability of data instrument.

TABLE 1: SAMPling TABLE

Population Sample Population Sample Population Sample

\begin{tabular}{llllll} 
Size & Size & Size & Size & Size & Size \\
\hline 95 & 76 & 480 & 214 & 5000 & 357 \\
100 & 80 & 500 & 217 & 6000 & 361 \\
110 & 86 & 550 & 226 & 7000 & 364 \\
\hline
\end{tabular}

Source: Krejcie and Morgan's (1970)

\section{RESULTS AND DISCUSSION}

The correlation is a statistical measure that describes the size and type of association whether it is positive or negative between two or more variables. The normal value range for the correlation 
coefficient is between -1 and +1 . The output of the correlation matrix in Table 2 shows that the correlation between training and the employees' productivity. A correlation of $r=0.511(\rho$ $<.0005, \rho=0.000$ ) suggests a strong positive correlation between these two variables and mentions the value of training to enhance employees' productivity in the in the UAE (GDRFA).

\begin{tabular}{|c|c|c|c|}
\hline & EMPLOYEES & $\frac{\text { ODUCTIVITY }}{\text { Training }}$ & Productivity \\
\hline \multirow{3}{*}{ raining } & $\begin{array}{l}\text { Pearson } \\
\text { Correlation }\end{array}$ & 1 & $.511^{* * *}$ \\
\hline & Sig. (2-tailed) & & .000 \\
\hline & $\mathrm{N}$ & 387 & 387 \\
\hline \multirow{3}{*}{ roductivity } & $\begin{array}{l}\text { Pearson } \\
\text { Correlation }\end{array}$ & $.511^{* *}$ & 1 \\
\hline & Sig. (2-tailed) & .000 & \\
\hline & $\mathrm{N}$ & 387 & 387 \\
\hline
\end{tabular}

In statistics, simple linear regression predicts the change in the dependent variable as the independent variable changes. Mathematical modeling and statistical modeling is used when there are dependent and independent variables. The model determines the relationship between the former and the latter variable. The dependent variables represent the output of variation and the independent variable presents inputs, i.e. potential reasons for variation. The results of the regression between training and employees' productivity are shown in the three outputs tables (model summary table, ANOVA table, and coefficients table).

\section{A. The Model Summary of Simple Linear Regression}

The model summary provides initial information about the regression strength between training and employees' productivity. From the Table 3, the study identifies the simple correlation coefficient $(\mathrm{R})$, the coefficient of determination $\left(\mathrm{R}^{2}\right)$, and the adjusted R-Square.

TABle 3: MODEL SUMMARY OF SiMPLE LiNEAR REGRESSION OUTPUT BETWEEN TRAINING AND EMPLOYEE PERFORMANCE

\begin{tabular}{lllll}
\hline Model & $\mathrm{R}$ & R-Square & $\begin{array}{l}\text { Adjusted } \\
\text { R-Square }\end{array}$ & $\begin{array}{l}\text { Std. Error of the } \\
\text { Estimate }\end{array}$ \\
\hline 1 & $.511^{\mathrm{a}}$ & .261 & .259 & .41392 \\
\hline
\end{tabular}

a. Predictors: (Constant), Training

b. Dependent Variable: Productivity

Checking the values model summary enables the researcher to know how well the regression model predicts the observation of the variance and variability between the two variables. It is found that $R$ is equal to (0.511), this indicates good degree of association between training and employees' productivity. The $\mathrm{R}^{2}$ indicates how much of the total variation in the employees' productivity can be explained by training. The $\mathrm{R}^{2}=0.261$ indicates that $(26.10 \%)$ of the variance in employees' productivity can be explained and interpreted by the variance in training. In other words, any change (variability) in employees' productivity is $26.10 \%$ predicted by the training. The remaining variance in employees' productivity which is equal to $(73.90 \%)$ is presumed to be due to random variability not related to training. Next output data is the adjusted R-squared which compares the explanatory power of regression models that contain different numbers of predictors. In this model, SPSS adjusted $25.90 \%$ of the variance between training and employees' productivity, where this value shows a small difference $(0.002)$ between the adjusted $\mathrm{R}^{2}$ and predicted $\mathrm{R}^{2}$ which is statistically acceptable.

\section{B. ANOVA Output}

Table 4 in regression outputs which reports how well the regression equation fits the data. TABLE 4: ANOVA OUTPUT

\begin{tabular}{|c|c|c|c|c|c|c|}
\hline & Model & $\begin{array}{l}\text { Sum of } \\
\text { Squares }\end{array}$ & df & $\begin{array}{l}\text { Mean } \\
\text { Square }\end{array}$ & $\mathrm{F}$ & Sig. \\
\hline & Regression & 23.279 & 1 & 23.279 & 135.870 & $0.000^{\mathrm{b}}$ \\
\hline \multirow[t]{2}{*}{1} & Residual & 65.963 & 385 & 0.171 & & \\
\hline & Total & 89.242 & 386 & & & \\
\hline
\end{tabular}

a. Dependent Variable: Productivity

b. Predictors: (Constant), Training

In the ANOVA analysis, it is evident that the regression model predicts the dependent variable significantly well. In other words, the overall regression model statistically significantly predicts the outcome variable employee's productivity (i.e., the output of regression is a good fit for the data). In regression analysis, F-value and significance level of that F-value will be in the output. If the F-value is statistically significant $(\mathrm{p}<.05)$, this signifies that the model (the predictors) did a good job of predicting the outcome variable.

Furthermore, reading the data in Table 4 shows that the correlation between the two variables is statistically significant. The conclusion is made by comparing the $\rho$-value in the table below with the standard significance level $(\rho \leq$ 0.05). The last column in the below table shows that $(\rho=$ 0.000 ), therefore, accept the hypothesis H1. In addition to that the value of $F$ (135.870) which is equal to the ratio of two mean square values of training and employees' productivity is large. Thus the variation between the means of two variables is not by chance. In other words, there is a causal relationship between training and employees' productivity. According to that, the hypothesis (H1) is true.

\section{Regression Coefficients}

The Coefficients table provides the necessary information to predict employees' productivity from training. Also it is helpful to determine whether training contributes significantly to the regression model.

TABLE 5: COEFFICIENTS OF REGRESSION

\begin{tabular}{|c|c|c|c|c|c|}
\hline \multirow{3}{*}{ Model } & \multirow{2}{*}{\multicolumn{2}{|c|}{$\begin{array}{l}\text { Unstandardized } \\
\text { Coefficients }\end{array}$}} & \multirow{3}{*}{$\begin{array}{l}\text { Standardized } \\
\text { Coefficients } \\
\text { Beta }\end{array}$} & \multirow{3}{*}{$\mathrm{t}$} & \multirow{3}{*}{ Sig. } \\
\hline & & & & & \\
\hline & B & $\begin{array}{l}\text { Std. } \\
\text { Error }\end{array}$ & & & \\
\hline \multirow[t]{2}{*}{ (Constant) } & 2.055 & .11 & & 18.061 & 0.000 \\
\hline & 0.391 & $4^{.03}$ & 0.511 & 11.656 & 0.000 \\
\hline
\end{tabular}

a. Dependent Variable: Productivity

Reading the level of significance in the last column Table 5 shows that the regression equation is statistically significant ( $\rho=0.000$ ). Also, the unstandardized coefficient (B) is positive i.e. 0.319. Therefore, it is concluded that the change in training positively predicts employees' productivity. 


\section{CONCLUSION}

Training is an important variable in the success of the organization. It consists of three factors (learning, reaction, and behavior).

The reaction the first factor of training, scored above the middle degree of agreements, the respondents agree that the place of training was suitable for the implementation of the training program. The second-factor learning mentions that the desire to learn is one of the most important considerations for engaging in training programs and the information gained from the training help employees to better understand the tasks they are doing. After training, employees confirmed they the skills that they have learnt will contribute to enhance the productivity at work. The last factor of training to test was the behavior of employees. The result shows that employees' confidence increased and training changed the relationship among staff after the training. Also, trainees' behavior improved after the training program. Thus, it is clear that training improves staff confidence and relationship among them which leads to the increase in productivity

\section{REFERENCES:}

[1] Abomeh, O. S., \& Peace, N. N. (2015). Effects of training on employees' productivity in Nigeria insurance industry. Journal of Economics, Management and Trade, 227-235.

[2] Chiaburu, D. S., \& Tekleab, A. G. (2005). Individual and contextual influences on multiple dimensions of training effectiveness. Journal of European Industrial Training, 29(8), 604-626.

[3] Fakhar, U. F., \& Anwan, K. (2008). Case of Pearl continental hotels in Pakistan, relationship training with employees performance in Hoteling Industry.

[4] Haynes, B. P. (2007). The impact of the behavioural environment on office productivity. Journal of facilities management, 5(3), 158-171.

[5] Kirkpatrick, D., \& Kirkpatrick, J. (2013). KIRKPATRICK FOUR LEVELS.

[6] Konings, J., \& Vanormelingen, S. (2015). The impact of training on productivity and wages: firm-level evidence. Review of Economics and Statistics, 97(2), 485-497.

[7] Koopmans. L. Bernaards. C. M. Hildebrandt. V. H. Schaufeli. W. B. de Vet Henrica. C. W. \& van der Beek. A. J. (2011). Conceptual Frameworks of Job performance. Journal of Occupational and Environmental Medicine. 53(8). pp. 856-866.

[8] Krejcie, R. V., \& Morgan, D. W. (1970). Determining sample size for research activities. Educational and psychological measurement, 30(3), 607-610.

[9]

[10] Lindström, S., \& Vanhala, S. (2013). Performance in local government HRM: the role of external customers. Baltic Journal of Management, 8(3), 252-268.

[11] Nda, M. M., \& Fard, R. Y. (2013). The impact of employee training and development on employee productivity. Global Journal of commerce and management perspective, 2(6), 91-93.

[12] Prada, M. F., Rucci, G., \& Urzúa, S. (2019). Training, Soft Skills and Productivity: Evidence from a Field Experiment in Retail (No. 9647). Inter-American Development Bank.

[13] Robert I. S. (2006). Organizational Performance as Dependent Variable. Scandinavian Consortium for Organizational Research.

[14] Saunders, M. N. (2011). Research methods for business students, 5/e. Pearson Education India.

[15] Sultana, A., Irum, S., Ahmed, K., \& Mehmood, N. (2012). Impact of training on employee performance: A study of telecommunication sector in Pakistan. Interdisciplinary Journal of contemporary research in business, 4(6), 646-661.

[16] Trevisani, D. (2016). Communication for leadership: Coaching leadership skills. Medialab Research, Ferrara.

\section{AUTHORS PROFILE}

Rashid Ali Al Ali, Faculty of Technology Management, Universiti Tun Hussein Onn Malaysia, 86400 Parit Raja, Batu Pahat, Johor, Malaysia. rashed_alalili@hotmail.com

Rosman MD Yusoff, Centre for General Studies and Co-Curricular, Univeristi Tun Hussein Onn Malaysia, 86400 Parit Raja, Batu Pahat, Johor, Malaysia.rosmanmy@uthm.edu.my

Fadillah Binti Ismail, Faculty of Technology Management, Universiti Tun Hussein Onn Malaysia, 86400 Parit Raja, Batu Pahat, Johor, Malaysia. fadillah@uthm.edu.my

Adnan Ali Alhisani, Faculty of Technology Management, Universiti Tun Hussein Onn Malaysia, 86400 Parit Raja, Batu Pahat, Johor, Malaysia. dnanvip@ hotmail.com. 